\section{Southern Blight-resistant Tomato Breeding Lines: 5635M, 5707M, 5719M, 5737M, 5876M, and 5913M}

Paul W. Leeper ${ }^{1}$

Texas A\&M University Research Center, Weslaco, TX 78596-8399

\author{
Sharad C. Phatak ${ }^{2}$ and Durham K. Bell ${ }^{3}$ \\ Coastal Plain Experiment Station, University of Georgia, Tifton, \\ GA 31793
}

\section{Ben F. George ${ }^{4}$}

Heinz U.S.A., P.O. Box 57, Tracy, CA 95378-0057

\section{Edward L. Cox ${ }^{5}$, George E. Oerther, and Brian T. Scully ${ }^{7}$ Texas A\&M University Research Center, Weslaco, TX 78596-8399}

Additional index words. disease resistance, Fusarium oxysporum f. lycopersici, Lycopersicon esculentum, pedigree breeding, phellem barrier, Sclerotium rolfsii, Stemphylium solani, vegetable breeding

Southern blight, incited by the fungus Sclerotium rolfsii Sacc., is a soil-borne pathogen that is ubiquitous in the tropics, subtropics, and subtemperate regions of the world. It infects $>200$ plant species and is an important disease of tomato (Lycopersicon esculentum Mill.) on warm ( $\geq 30 \mathrm{C})$, noncalcareous acid soils (Sherf and MacNab, 1986). Presently, the only sources of resistance to $S$. rolfsii are selections from wild Peruvian accessions of $L$. pimpinellifolium Mill. (PI 126932 and PI 126432); high levels of resistance are not currently deployed in tomato (Mohr, 1955; Mohr and Watkins, 1959; Phatak and Bell, 1983). As a result, management practices for this disease have relied heavily on crop rotation and application of chemicals. Because S. rolfsii has longterm soil persistence and an extremely wide host range and geographic distribution, genetic resistance is economically important and

Received for publication 22 Apr. 1991. Accepted for publication 27 Dec. 1991. TAES Technical Article no. 17376. This research was supported in part by the South Texas Tomato Committee and a cooperative grant from Heinz U.S.A. The cost of publishing this paper was defrayed in part by the payment of page charges. Under postal regulations, this paper therefore must be hereby marked advertisement solely to indicate this fact.

'Professor Emeritus.

${ }^{2}$ Professor.

${ }^{3}$ Associate Professor.

${ }^{4}$ National Manager-Agricultural Research.

${ }^{5}$ Assistant Professor. Presently: Asgrow Seed Co., Inc., Box 2247, El Centro, CA 92243.

${ }^{6}$ Research Technician.

${ }^{7}$ Assistant Professor and corresponding author. Presently: Everglades Research and Education Center, IFAS, University of Florida, Belle Glade, FL 33430-8003. a useful tactic for the control of southern blight.

Symptoms on tomato typically include dark brown or black lesions that usually appear near the soil surface on herbaceous stems or soft vegetative tissue. With soil moistures at or above field capacity, lesions expand rapidly on the roots and shoots. A white mycelium extends radially up the stem and later produces 1 - to 2-mm-diameter sclerotia. Infected plants are partially or fully girdled, which causes seedlings to damp-off, while mature plants progress through a leaf yellowing and wilting phase that begins on the lower leaves. Fruits near or in contact with the soil can also become infected. The fungus penetrate's the epidermis of the fruit and develops surface lesions that are yellowish and sunken. As lesions enlarge from 10 to $20 \mathrm{~mm}$, the fruit surface cracks and becomes water-soaked. Fruits can rot in 3 or 4 days under ideal temperature and moisture (Jones et al., 1991; McColloch et al., 1968).

Resistance is attributed to the precocious development of secondary tissue (periderm) on the basal mainstem. Resistant individuals develop an overlapping phellem barrier five to six cell layers deep as 6- to 9-week-old seedlings. Destruction of the phellem barrier allows entry of the pathogen and results in a loss of resistance. Conversely, increases in plant tissue $\mathrm{Ca}$ levels confer more resistance. to susceptible genotypes (Mohr, 1955; Watkins et al., 1958).

\section{Origin}

General. This breeding program was originally intended to develop heat-tolerant processor-type tomato cultivars suitable for machine harvest. Routine evaluation for southern blight resistance revealed that certain lines or plants within lines carried superior resistance under field conditions. These southern blight-resistant (SBR) breeding lines were

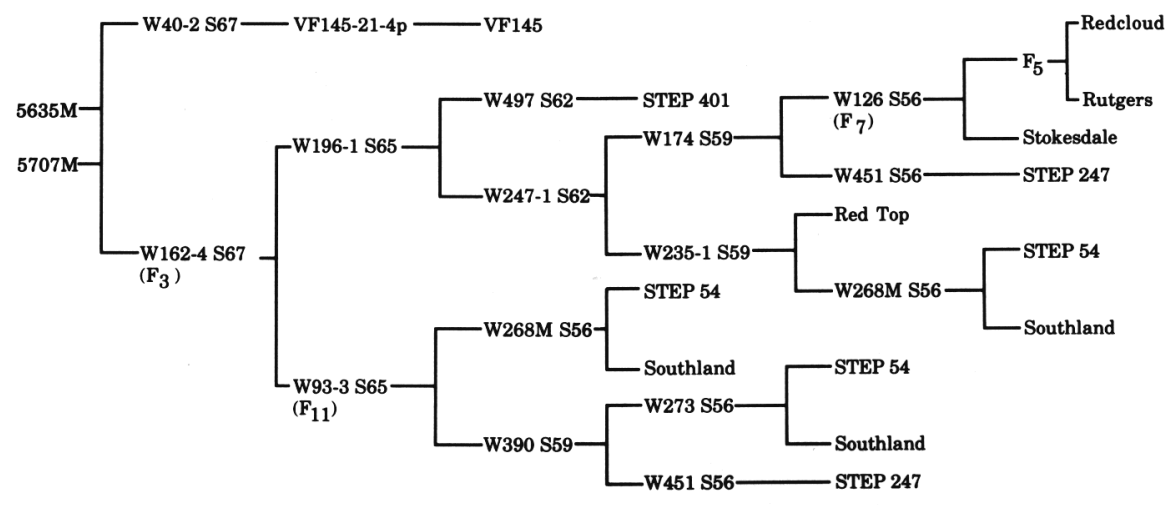

Fig. 1. Pedigree of 5635M and 5707M, southern blight-resistant tomato breeding lines.

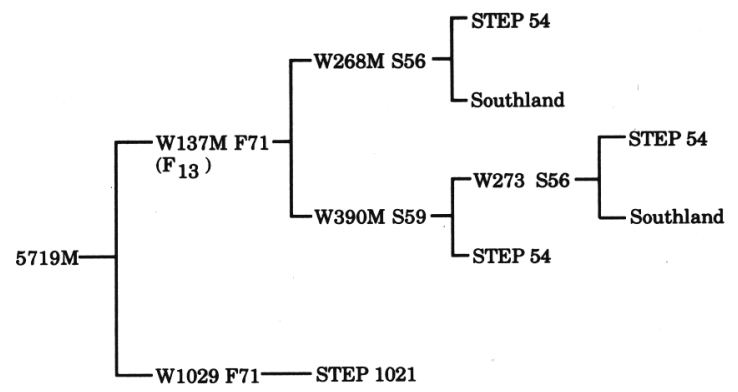

Fig. 2. Pedigree of 5719M, a southern blight-resistant tomato breeding line. 


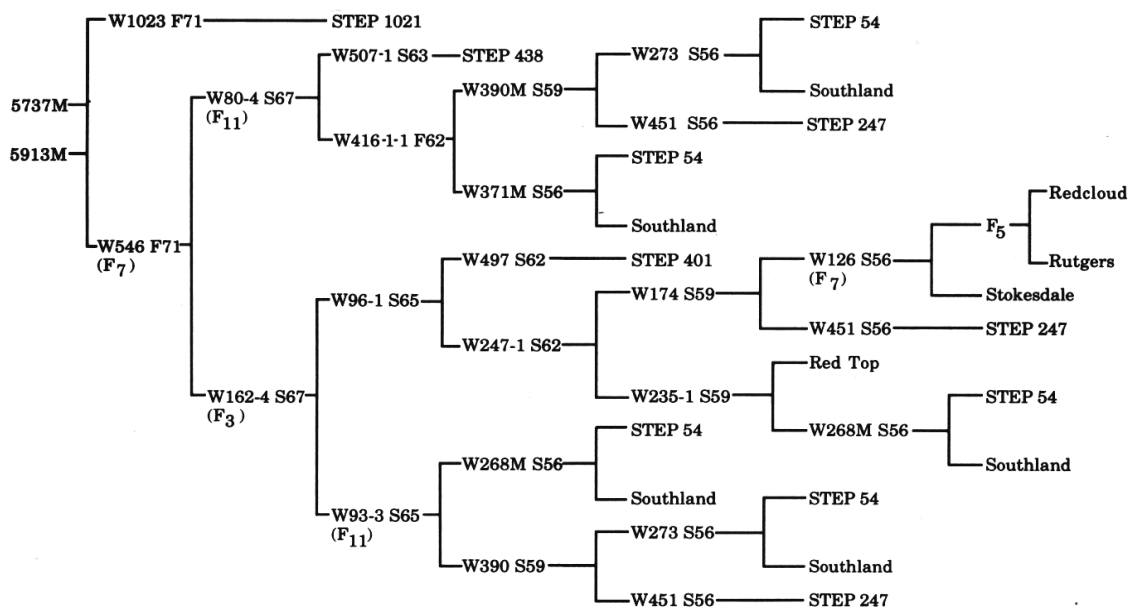

Fig. 3. Pedigree of $5737 \mathrm{M}$ and $5913 \mathrm{M}$, southern blight-resistant tomato breeding lines.

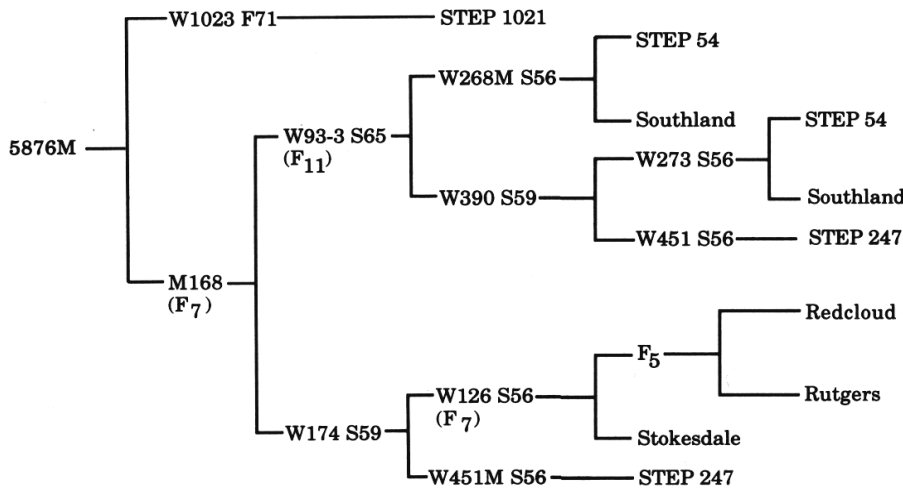

Fig. 4. Pedigree of $5876 \mathrm{M}$, a southern blight-resistant tomato breeding line.

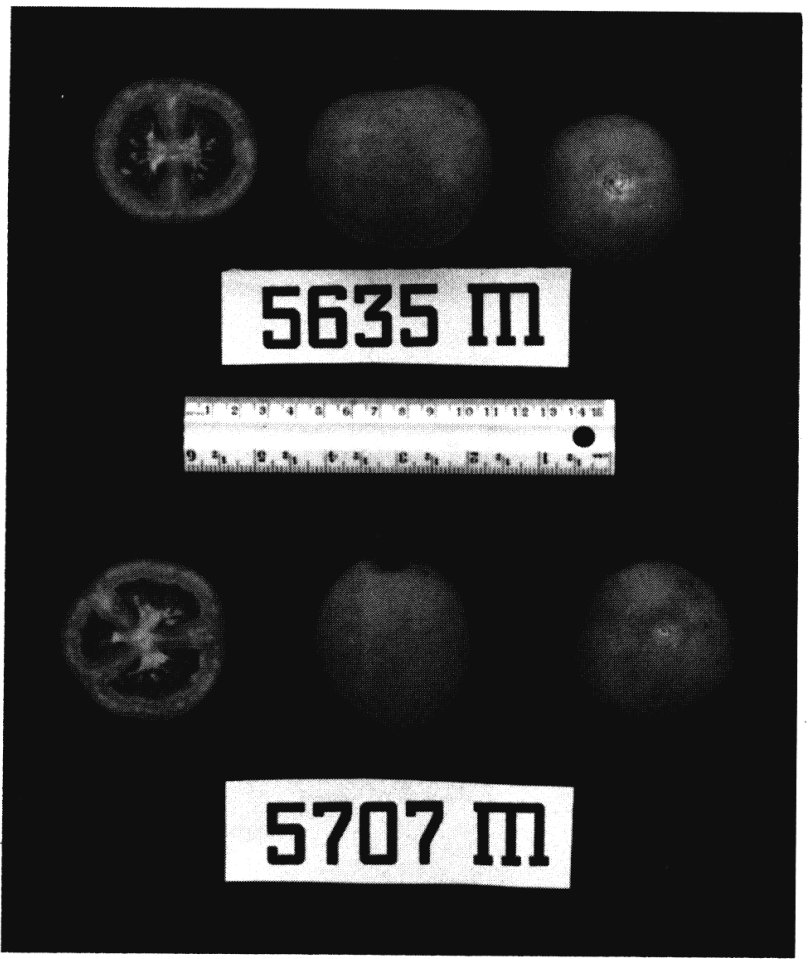

Fig. 5. Fruits of $5635 \mathrm{M}$ and $5707 \mathrm{M}$, southern blight-resistant tomato breeding lines. developed by a modified pedigree method that included multiple crosses (usually four to 14) and featured single-plant selection and mass selection. The final six selections were derived from an initial group of 309 advanced breeding lines screened over four generations. Fifty-six lines and/or individuals of the 309 lines survived the southern blight nursery on the Mississippi delta near Cleveland, Miss.; these were subsequently inoculated and planted in a field at Tifton, Ga. Twenty-one of these lines were selected for uniformly high levels of resistance and horticultural type and then were inoculated in the greenhouse and grown a third time in fields artificially infested with $S$. rolfsii (Phatak and Bell, 1983). These 21 lines were again inoculated in the greenhouse and transplanted to an infested field to confirm resistance. From this group, six lines were selected for superior resistance and phenotype.

This breeding program began in 1951 with a bulk $\mathrm{F}_{2}$ progeny derived from a cross between STEP 54 and 'Southland' made in 1950 (B.A. Perry, personal communication) (Table 1). The original source of resistance was not specifically known, but $F_{11}$ Weslaco breeding lines W268M S56 and W273 S56 were common throughout all six pedigrees (Figs. 1-4), and were derived from the STEP $54 \times$ 'Southland' cross. These two breeding lines were the putative source of resistance. Another $\mathrm{F}_{11}$ line (W371M S56) derived from this same cross (Fig. 3) was used in the development of $5737 \mathrm{M}$ and $5913 \mathrm{M}$, and may also have contributed resistance to southern blight. Other cultivars or breeding lines used in the development of the SBR lines included 'Redcloud', 'Red Top', 'Rutgers', STEP 54, STEP 247, STEP 401, STEP 438, STEP 1021, 'Stokesdale', and VF 145 (Table 1). Crosses among the Weslaco breeding lines derived from the STEP $54 \times$ 'Southland' progeny began in 1956, and the final crosses were made in the late 1960 s or early 1970 s. The final generations of each SBR line were bulked for release at $\mathrm{F}_{13}$ or beyond.

Weslaco breeding lines are indicated as "W" followed by a field entry number (Figs. $1-4)$. Field entry numbers followed by an "M" indicate a bulk population from mass selection. Subsequent codes represent the fall (F) or spring (S) season and the year of selection. The level of inbreeding specific to each line is determined as two generations from one crossing year to the next, unless otherwise noted. The numbers assigned to these six lines were incidental plot numbers.

$5635 \mathrm{M}$ and $5707 \mathrm{M}$. These $\mathrm{F}_{14}$ sib lines resulted from eight crosses made in 1967 (1), 1965 (1), 1962 (1), 1959 (2), and 1956 (3) (Fig. 1). W268M S56 was used as a parent in 1956 and 1959, while W273 S56 was used only in 1956. Original parental material included 'Redcloud', 'Red Top', 'Rutgers', STEP 54, STEP 247, STEP 401, 'Stokesdale', 'Southland', and VF 145, which had L. pimpinellifolium in its pedigree (Fig. 1) (Scott, 1983). The W126 S56 line was derived from a ('Redcloud' $x$ 'Rutgers') $\mathrm{F}_{\mathrm{s}} \times$ 'Stokesdale' cross made in the late 1940s 


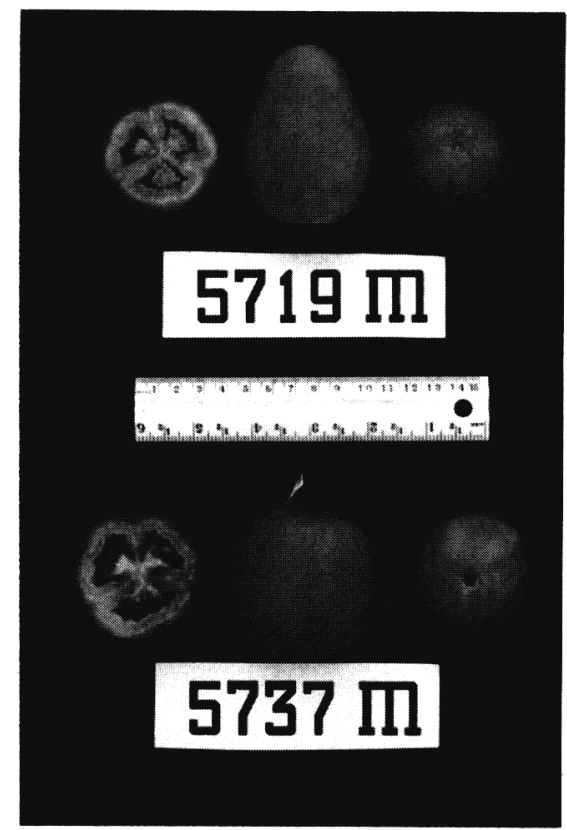

Fig. 6. Fruits of $5719 \mathrm{M}$ and $5737 \mathrm{M}$, southern blight-resistant tomato breeding lines.

Table 1. Sources of cultivars and breeding lines used to develop southern blight (Sclerotium rolfsii) resistant breeding lines.

\begin{tabular}{|c|c|}
\hline $\begin{array}{l}\text { Cultivar or } \\
\text { breeding line }\end{array}$ & Originator \\
\hline $\begin{array}{l}\text { Redcloud } \\
\text { Red Top }\end{array}$ & $\begin{array}{l}\text { Univ. of Nebraska, Lincoln } \\
\text { Cornell Univ., Ithaca, N.Y. }\end{array}$ \\
\hline Rutgers & $\begin{array}{l}\text { Rutgers Univ., New Brunswick, } \\
\text { N.J. }\end{array}$ \\
\hline STEP 54 & Univ. of Hawaii, Manoa \\
\hline STEP 247 & USDA-ARS, Charleston, S.C. \\
\hline STEP 401 & USDA-ARS, Beltsville, Md. \\
\hline STEP 438 & $\begin{array}{l}\text { Tropical Res. and Educ. } \\
\text { Ctr., IFAS, Univ. of } \\
\text { Florida, Homestead }\end{array}$ \\
\hline STEP $1021^{z}$ & $\begin{array}{l}\text { Tropical Res. and Educ. } \\
\text { Ctr., IFAS, Univ. of } \\
\text { Florida, Homestead }\end{array}$ \\
\hline Stokesdale & Stokesdale Seed Co. \\
\hline Southland & USDA-ARS, Charleston \\
\hline VF 145 & Univ. of California, Davis \\
\hline
\end{tabular}

${ }^{2}$ STEP numbers $>1000$ indicate a series of processor type tomatoes that were distributed for evaluation in the late 1960s and early 1970s (J.W. Scott, personal communication).

\section{(B.A. Perry, personal communication).}

$5719 M$. This line was inbred to $\mathrm{F}_{13}$, derived from a simple pedigree that included four crosses, each made in 1971, 1959, 1956, and 1950 (Fig. 2). The original parents used in the development of 5719M included 'Southland', STEP 54, STEP 247, and STEP 1021. W273 S56 and W268M S56 were used as parents in 1956 and 1959, respectively. The last cross was between a selection from STEP 1021 (W1029 F71) and an $\mathrm{F}_{13}$ breeding line (W137M P71) and STEP 54, STEP 247, and 'Southland' in its background (Fig. 2).

$5737 M$ and $5913 M$. These sib lines were inbred to $\mathrm{F}_{13}$ from a final cross made in 1971 between a selection (W1023 F71) derived from STEP 1021 and an $\mathrm{F}_{7}$ breeding line

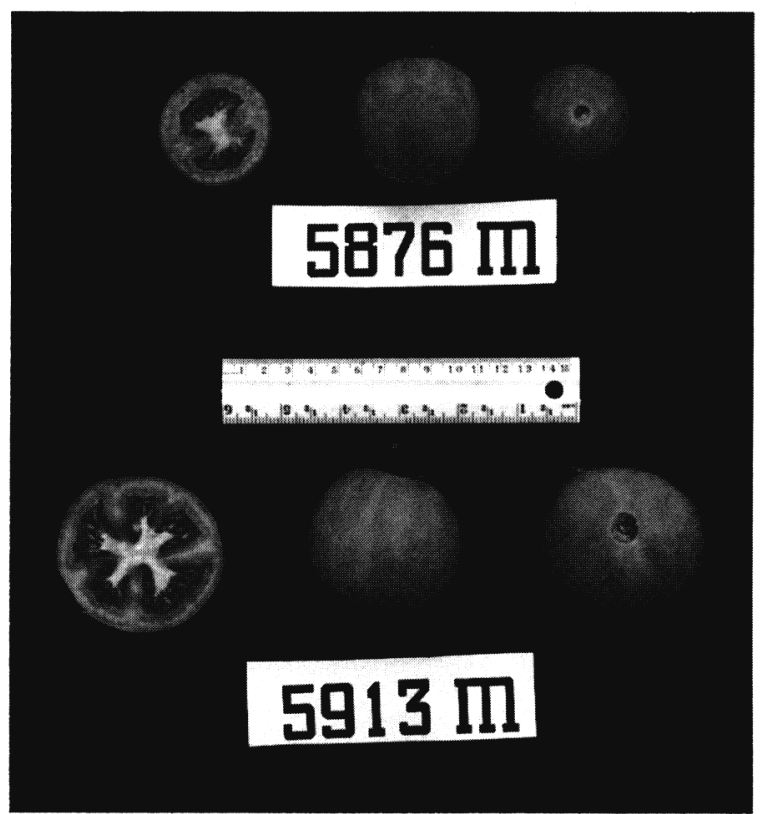

Fig. 7. Fruits of $5876 \mathrm{M}$ and $5913 \mathrm{M}$, southern blight-resistant tomato breeding lines.

numbered W546 F71 (Fig. 3). This line derived from a background of 11 crosses among Weslaco breeding lines that were made in 1967 (1), 1965 (1), 1963 (1), 1962 (1), 1959 (3), and 1956 (4). The original parents included 'Redcloud', 'Red Top', 'Rutgers', STEP 54, STEP 247, STEP 401, STEP 438, STEP 1021, 'Stokesdale', and 'Southland' (Fig. 3). W273 S56 was used as a parent twice in 1956, while W268M S56 was used once in 1956 and 1959. W371 S56 was another progeny line derived from the STEP 54 by 'Southland' cross and was used as a parent in 1959.

$5876 M$. This $\mathrm{F}_{13}$ line arose from a cross made in 1971 between a selection (Fig. 4). M168 derived from four crosses among Weslaco breeding lines made in 1965 (1), 1959 (1) and 1956 (2). W273 S56 was crossed with a selection from STEP 247 (W451 S56) in 1956, while W268M S56 was used as a parent in 1959. Included in the pedigree of 5876M was 'Redcloud', 'Rutgers', STEP 54, STEP 247, STEP 1021, 'Stokesdale' and 'Southland'.

\section{Description}

General. Plants were inoculated with Tomato Isolates $S c r 20,24,30$, and 32 of $S$. rolfsii isolated from fruits and plants using the procedure developed by Phatak and Bell (1983). Resistance was assessed on the basis of vegetative and root response to the pathogen. Fruits were not specifically challenged with the pathogen, but showed superior tolerance when grown in fields infested with $100 \mathrm{~kg} \mathrm{~S}$. rolfsii /ha. Plant survival of these SBR lines was compared to the wild PI 126432 (L. pimpinellifolium) selection and 'Arc', the resistant and susceptible controls, respectively (Table 2). Over 2 years, survival of the SBR lines was equivalent to the resistant PI 126432. Preliminary yield data indicated that $5719 \mathrm{M}$ and $5876 \mathrm{M}$ had su-
Table 2. Comparison of plant survival and yield of southern blight-resistant tomato breeding lines (M) and two controls in an infested field over 2 years at Tifton, Ga.

\begin{tabular}{lccc}
\hline \hline $\begin{array}{l}\text { Cultivar or } \\
\text { breeding } \\
\text { line }\end{array}$ & $\begin{array}{c}\text { USDA plant } \\
\text { introduction } \\
\text { (PI) no. }\end{array}$ & $\begin{array}{c}\text { Plants } \\
\text { surviving } \\
(\%)\end{array}$ & $\begin{array}{c}\text { Mean fruit } \\
\text { biomass }\end{array}$ \\
\hline (kg/plant)
\end{tabular}

${ }^{2}$ Mean separation with Duncan's multiple range test at $P \leq 0.05$.

perior average plant yields in Tifton (Table 2).

Plants of all six lines are small, determinate vines about one-third the size of 'Chico III' (Leeper, 1969) and have a high harvest index. Leaf margins tend to curl toward the midrib, and sometimes have a purple tint in the veins on the underside of the leaf. Fruit set is compact and dense, commonly with four to six fruits per inflorescence. Fruit color is medium to dark red, with fruit shape, size, and quality appropriate for processing. Crack resistance is equivalent to 'Chico III', and plants are adapted for fruit set at high relative humidities $(65 \%$ to $95 \% \mathrm{RH})$, and high temperatures (34 to 36C). Lines $5707 \mathrm{M}, 5737 \mathrm{M}$, and $5876 \mathrm{M}$ have similar maturity and are commonly a few days to 1 week earlier than $5635 \mathrm{M}, 5719 \mathrm{M}$, and 5913M. In addition to southern blight resistance, each line exhibited field resistance to race 1 of fusarium wilt [Fusarium oxysporum $f$. lycopersici (Sacc.) Snyder and Hansen] and gray leaf spot (Stemphylium solani Weber). These lines are genetically stable, near commercial quality, and suitable for evaluation in hybrid combinations. However, sufficient genetic di- 
versity was maintained within these releases to permit the selection of unique genotypes.

$5635 M$. Fruits of this line are globe- to plum-shaped with two to three locules (mostly two) and carried on jointed pedicels. Fruits range in size from 55 to $70 \mathrm{~mm}$ long and 45 to $60 \mathrm{~mm}$ wide; wall thickness averages $7 \mathrm{~mm}$. The stem scar is 6 to 12 $\mathrm{mm}$ wide, and the blossom end is slightly apiculate $(\geq 1 \mathrm{~mm})$. Fruits average $73 \mathrm{~g}$ and ripen uniformly.

$5707 M$. Fruits are plum-shaped with two to four locules (mostly three) and range in size from 60 to $70 \mathrm{~mm}$ long, 45 to $55 \mathrm{~mm}$ wide, with an average wall thickness of 7.0 to $8.0 \mathrm{~mm}$ (Fig. 5). Fruits are carried on jointed pedicels with a stem scar 4.0 to 8.0 $\mathrm{mm}$ wide. The blossom end is strongly apiculate, ranging from 3 to $8 \mathrm{~mm}$. Average fruit weight is $68 \mathrm{~g}$; they ripen uniformly.

$5719 \mathrm{M}$. This line produces nearly pearshaped fruits 6.4 to $8.5 \mathrm{~cm}$ long with a widest diameter of 45 to $50 \mathrm{~mm}$ and 20 to 30 mm width at the neck (Fig. 6). Fruits mostly have three locules, with a fruit wall thickness that ranges from 6 to $7 \mathrm{~mm}$. The blossom end of the fruit has a 1- to 3-mm apicule, while the stem end has a 4.0- to 5.0-mm scar when detached from a jointed pedicel. Fruits average $50 \mathrm{~g}$ and ripen uniformly.

$5737 M$. Rounded to blocky pear-shaped fruits are carried on jointless pedicels and commonly range from 55 to $75 \mathrm{~mm}$ long with a maximum diameter of 45 to $60 \mathrm{~mm}$ (Fig. 6). Fruits are mostly three-loculed, occasionally puffy, with 6.0 - to 7.0 -mm-thick walls. The stem end of the fruit has a 6.0to $7.0-\mathrm{mm}$ scar, while the blossom end is smooth to slightly recessed. Fruits are greenshouldered and average $55 \mathrm{~g}$.

$5876 M$. Fruits are mostly blocky with a tendency toward rounded to pear shapes that average 50 to $70 \mathrm{~mm}$ long, 40 to $55 \mathrm{~mm}$ wide, with three to four locules (mostly three) and are occasionally puffy (Fig. 7). Fruit walls average 6.0 to $8.0 \mathrm{~mm}$. Pedicels are jointed and leave a $6.0-$ to $9.0-\mathrm{mm}$ stem scar when detached from the fruit. The blossom end of the fruit is smooth to slightly recessed $(\geq 1 \mathrm{~mm})$. Fruits ripen uniformly and average $\approx 45 \mathrm{~g}$.

$5913 M$. Fruit of this line vary from blocky pear to blocky round, and range in size from 50 to $65 \mathrm{~mm}$ long and 40 to $60 \mathrm{~mm}$ in diameter. This line also is heterogenous for jointed and jointless pedicels, with fruits that have three or four locules and walls 4.0 to $7.0 \mathrm{~mm}$ thick. The stem scar is 7 to $13 \mathrm{~mm}$ wide, while the blossom end is smooth to recessed $(\geq 1 \mathrm{~mm})$. Fruits ripen uniformly and average $86 \mathrm{~g}$.

\section{Availability}

These six southern blight-resistant breeding lines are a public release from Texas A\&M Univ. Foundation seed was deposited with the Foundation Seed Service of Texas A\&M Univ., College Station TX, 77843. Breeders seed has also been deposited in the U.S. Dept. of Agriculture tomato collection held in Geneva, N.Y., and plant introduction numbers have been assigned (Table 2). For research purposes, small samples of seed are available from G.E.O.

\section{Literature Cited}

Jones, J.B., J.P. Jones, R.E. Stall and T.A. Zitter. 1991. Compendium of tomato diseases. Amer. Phytopathol Soc., St. Paul, Minn.

McColloch, L.P., H.T. Cook, and W.R. Wright. 1968. Market diseases of tomatoes, peppers, and eggplants. Agr. Hdbk. no. 28, U.S. Dept. Agr.Agr. Res. Serv., D.C.

Leeper, P.W. 1969. TAMU 'Chico III': A pear type, disease resistant tomato designed for machine harvest. Expt. Sta. Bul. no. L-810, Texas A\&M Univ., College Station.

Mohr, H.C. 1955. Resistance in Lycopersion pimpinellifolium Mill. to southern blight caused by Sclerotium rolfsii Sacc. PhD Diss., M699, Texas A\&M Univ., College Station.

Mohr, H.C. and G.M. Watkins. 1959. The nature of resistance to southern blight in tomato and the influence of nutrition on its expression. Proc. Amer. Soc. Hort. Sci. 74:484-493.

Phatak, S.C. and D.K. Bell. 1983. Screening for Sclerotium rolfsii resistance in the tomato. Proc. 4th Tomato Quality Wrkshp, Veg. Crops Res. Rpt., VEC-83-1, Dept. Veg. Crops, Inst. Food and Agr. Sci., Univ. of Florida, Gainesville. p. 107.

Scott, J.W. 1983. Genetic sources of tomato firmness. Proc. 4th Tomato Quality Wrkshp., Veg. Crops Res. Rpt., VEC-83-1, Dept. of Veg. Crops, Inst. Food Agr. Sci., Univ. of Florida, Gainesville. p. 60-67.

Watkins, G.M., H.C. Mohr, and P.A. Young. 1958. Control of southern blight in tomatoes in northeast Texas. Phytopathology 48:346. 